\title{
Pengaruh Kualitas Sistem Informasi Terhadap Kepuasan Pengguna Pada SMA Al - Huda Cengkareng
}

\author{
Impact of Information System Quality Towards User Satisfaction at SMA Al-Huda \\ Cengkareng
}

\author{
Imam Mahfuji Jaya ${ }^{1}$, Jenie Sundari ${ }^{2}$ \\ ${ }^{1,2}$ Jl. Damai No. 8 Warung Jati Barat, Jakarta Selatan (021-78839502) \\ Jurusan Teknik Informatika, STMIK Nusa Mandiri Jakarta

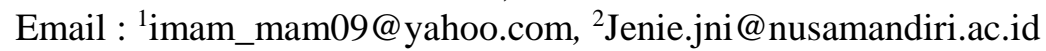

\begin{abstract}
Abstrak
Penerapan Sistem Informasi menjadi kebutuhan yang mutlak dan dapat memberikan keunggulan kompetitif, sehingga menjadi perioritas tertinggi. Sistem Informasi Penilaian merupakan sistem yang diteliti pengaruhnya terhadap kepuasan pengguna di lingkungan SMA Al-Huda. Dalam penelitian ini diuji pengaruh kualitas sistem informasi terhadap kepuasan pengguna dengan menggunakan dasar metode kesuksesan DeLone dan McLean. Penelitian ini menggunakan pendekatan kuantitatif dengan pemetaan karakteristik data dengan cara deskriptif statistik. Hasil penelitian menunjukkan bahwa Kualitas Sistem (X1) dan kualitas informasi (X2) berpengaruh baik secara bersama-sama terhadap kepuasan pengguna (Y) Sistem Informasi Penilaian. Nilai signifikan t untuk kualitas sistem lebih kecil dari $\alpha$ yang ditetapkan $(\alpha=0,05)$ yaitu 0,000 . Selain itu, hasil pengujian ini juga menunjukkan nilai $t$ hitung lebih besar dari nilai $t$ tabel $(2,871>1,686)$ untuk kualitas sistem informasi, Berdasarkan hasil pengujian tersebut maka dapat disimpulkan bahwa $\mathrm{H}_{0}$ diterima dan Signifikansi untuk t kualitas informasi 0,000. Sehingga nilai probabilitas $0,00<0,005$ Dan nilai $\mathrm{t}$ hitung lebih besar dari $\mathrm{t}$ tabel $(2,973>1,686)$, sehingga dapat diputuskan bahwa $\mathrm{H}_{1}$ diterima. Artinya kualitas informasi berpengaruh positif terhadap kepuasan pengguna, hasil penelitian juga menyimpulkan bahwa kualitas sistem informasi memiliki pengaruh yang dominan terhadap kepuasan pengguna.
\end{abstract}

Kata kunci : kualitas sistem, kualitas informasi, kepuasan pengguna, Sistem informasi

\begin{abstract}
Abstrak
Application of Information Systems becomes an absolute necessity and can provide a competitive advantage, thus becoming the highest priorities. Assessment Information System is a system studied its impact on user satisfaction in the neighborhood of Al-Huda School. In this study tested the effect of the quality of information systems against user satisfaction using the basic method of success DeLone and McLean. This study uses a quantitative approach to mapping the characteristics of the data by means of descriptive statistics. The results showed that the Quality System (X1) and quality information (X2) effect either jointly against user satisfaction (Y) Information System Assessment. T significant value to the quality of the system is smaller than the specified $\alpha(\alpha=$ $0.05)$ is 0.000. In addition, the results of this test also showed the value of $t$ is greater than $t$ table (2.871> 1.686) for the quality of the information system, Based on the test results it can be concluded that $\mathrm{HO}$ is accepted and Significance for 0,000 t of quality information. So the probability value 0.00 $<0.005$ and $t$ value greater than t table (2.973>1.686), so it can be decided that H1 is accepted. This means that the quality of information has positive influence on user satisfaction, the results of the study also concluded that the quality of the information system has a dominant influence on user satisfaction.
\end{abstract}

Keyword : System quality, Information quality, User satisfaction, System information 


\section{PENDAHULUAN}

\subsection{Latar Belakang Masalah}

Perkembangan di bidang teknologi masa kini berkembang dengan pesat. Semakin berkembangnya teknologi terutama di bidang teknologi informasi membuat teknologi itu sendiri memegang peranan yang sangat penting di dalam suatu sekolah. Teknologi digunakan dalam setiap aspek operasional suatu sekolah bahkan sampai ke perumusaan strategi yang akan diambil oleh suatu sekolah. Hal ini berkaitan dengan fungsi teknologi sebagai penyedia informasi yang dibutuhkan oleh sekolah untuk menjalankan proses penilaiannya.

Pengguna sistem informasi tentu berharap bahwa dengan menggunakan sistem informasi akan memperoleh informasi yang mereka butuhkan. Sistem informasi yang digunakan oleh SMA Al-Huda saat ini adalah aplikasi Sistem Informasi Penilaian (SIP), sistem yang berbasis web intranet ini juga merupakan sistem internal yang berfungsi sebagai wadah informasi sekaligus menjadi alat yang digunakan dalam pembuatan nilai, dan Sistem SIP ini mengimplementasikan seluruh proses penilaian.

Dalam penelitian terdahulu yang dapat dikutip sebagai berikut: Kepuasan pengguna secara potensial dapat diukur oleh kegunaan sistem informasi yang mendukung dalam pembuatan keputusan. Informasi merupakan sumber daya yang sangat bernilai bagi suatu organisai karena proses kegiatan yang dilakukan suatu organisasi tidak akan berjalan sempurna, efektif dan efisien tanpa dukungan informsi yang baik. [1]

Kesuksesan penerapan Sistem Informasi Pelayanan Terpadu (SIPT) Online PT Jamsostek (Persero) dipengaruhi secara signifikan oleh kualitas sistem, kualitas informasi, kualitas pelayanan, dan kepuasan pengguna serta kesesuaian tugas dan teknologi. Kesuksesan penerapan SIPT Online diukur dengan menggunakan kepuasan pengguna sistem informasi serta dampak individual karena penggunaan sistem informasi. [2]

\subsection{Identifikasi Masalah}

1. Bagaimana pengaruh kualitas sistem informasi terhadap kepuasan penguna Sistem Informasi Penilaian.

2. Bagaimana pengaruh kualitas sistem informasi terhadap ktidakpuasan penguna Sisitem Informasi Penilaian.

\section{METODE PENELITIAN}

Metode yang digunakan untuk dalam penelitian ini adalah Metode Kualitatif. Metode penelitian yang penulis gunakan dalam rangka pengumpulan data dalam penelitan ini adalah sebagai berikut:

\section{a. Observasi ( Observation)}

Penulis mengumpulkan data melalui peninjauan langsung pada SMA Al-Huda. Penulis melihat secara langsung bagaimana penggunaan Sistem Informasi Penilaian dari tanggal 07 April 2015 sampai dengan 29 Mei 2015.

b. Wawancara (Interview)

Wawancara dilakukan kepada guru dan pegawai atau staff TU selaku pelaku kerja yang mengetahui tentang permasalahan serta proses operasional yang sedang berjalan serta memberikan kuisioner yang diisi oleh guru sebagai pengguna sistem.

c. Studi Pustaka (Library Reserch)

Menggunakan metode kepustakaan dengan mempelajari literatur, buku, catatan, dan sumber-sumber lain yang berkenaan penggunaan dan manfaat sistem informasi, 
sehingga penulis mendapatkan gambaran mengenai materi yang akan digunakan dalam membuat penelitian sistem.

2.1 Instrumen Penelitian

Variabel dalam penelitian kuantitatif dapat dibedakan menjadi 2 (dua) [4], yaitu :

1. Variabel Bebas (independent variable)

2. Variabel Terkait (dependent variable)

\section{Variabel Bebas}

(Independent Variable)

$\mathrm{X}$

\author{
Variabel Terikat \\ (Dependent Variable) \\ $\mathrm{Y}$
}

\section{Gambar 1. Hubungan Kausal Antara Variabel Bebas dan Variabel Terikat}

Skala Likert digunakan untuk mengukur sikap, pendapat dan persepsi seseorang atau sekelompok orang tentang fenomena sosial. [3] Untuk setiap pilihan jawaban diberi skor, maka responden harus menggambarkan, mendukung pernyataan. Untuk digunakan jawaban yang dipilih. Dengan skala Likert, maka variabel yang akan diukur dijabarkan menjadi indikator variabel. Variabel yang penulis penggambaran metode penelitian sebagai berikut :

Tabel 1: Skala Penilaian Skal Likert

Skala Penilaian Untuk Pernyataan Positif dan Negatif

\begin{tabular}{|c|l|c|c|}
\hline N0 & \multicolumn{1}{|c|}{ Keterangan } & Skor Positif & Skor Negatif \\
\hline 1. & Sangat Tidak Setuju & 5 & 1 \\
\hline 2. & Tidak Setuju & 4 & 2 \\
\hline 3. & Netral & 3 & 3 \\
\hline 4. & Setuju & 2 & 4 \\
\hline 5. & Sangat setuju & 1 & 5 \\
\hline \multicolumn{3}{|c|}{ (Sumber Sugiono, 2010:94) } \\
\hline
\end{tabular}

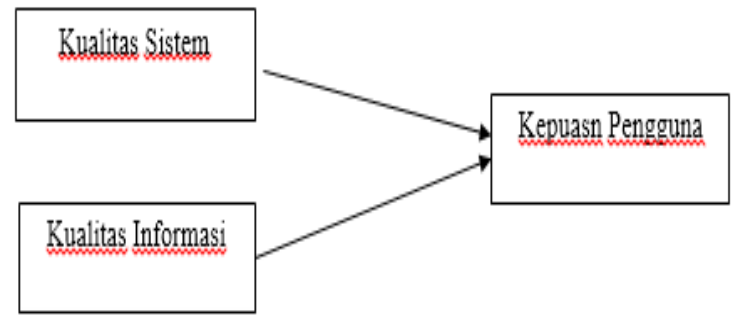

Gambar 2. Variabel Penelitian

Salah satu cara pengumpulan data primer dan sekunder yaitu diolah dengan menggunakan kuisioner dengan indikator sebagai berikut : 
Tabel 2 : Indikator Kuisioner Kualitas Sistem Informasi Terhadap Kepuasan Pengguna SIP

\begin{tabular}{|c|c|c|c|}
\hline Variabel & Dimensi & Indikator & $\begin{array}{l}\text { No Butir } \\
\text { Kuisioner }\end{array}$ \\
\hline \multirow{6}{*}{$\begin{array}{l}\text { Kualitas Sistem } \\
\text { (System Quality) }\end{array}$} & \multirow{2}{*}{ Fleksibilitas } & $\begin{array}{l}\text { Mudah digunakan dalam } \\
\text { lingkungan manapun }\end{array}$ & 1 \\
\hline & & $\begin{array}{l}\text { SIP dapat digunakan berbagai } \\
\text { karakteristik pengguna }\end{array}$ & 2 \\
\hline & \multirow{2}{*}{$\begin{array}{l}\text { Kemudahan } \\
\text { Penggunaan }\end{array}$} & $\begin{array}{l}\text { Tersedia koreksi data dalam } \\
\text { kesalahan input }\end{array}$ & 3 \\
\hline & & $\begin{array}{l}\text { Kesalahan mudah dikoreksi } \\
\text { dalam aplikasi tersebut }\end{array}$ & 4 \\
\hline & \multirow{2}{*}{$\begin{array}{l}\text { Keandalan } \\
\text { sistem }\end{array}$} & $\begin{array}{l}\text { Aplikasi dapat mudah } \\
\text { digunakan }\end{array}$ & 5 \\
\hline & & Aplikasi mudah dimengerti & 6 \\
\hline \multirow{5}{*}{$\begin{array}{l}\text { Kualitas Informasi } \\
\text { (Information } \\
\text { Quality) }\end{array}$} & \multirow{3}{*}{ Akurat } & $\begin{array}{l}\text { Informasi yang dihasilkan } \\
\text { akurat }\end{array}$ & 7 \\
\hline & & $\begin{array}{l}\text { Informasi yang dihasilkan dapat } \\
\text { dipercaya }\end{array}$ & 8 \\
\hline & & $\begin{array}{l}\text { puas dengan tingkat akurasi } \\
\text { aplikasi yang digunakan }\end{array}$ & 9 \\
\hline & Relevan & Informasi yang relevan & 10 \\
\hline & Kekinian & $\begin{array}{l}\text { Menghasilkan informasi up to } \\
\text { date }\end{array}$ & 11 \\
\hline \multirow{7}{*}{$\begin{array}{c}\text { Kepuasan } \\
\text { Pemakai/Pengguna } \\
\text { (User Satisfaction) }\end{array}$} & \multirow{2}{*}{$\begin{array}{l}\text { Kelengkapan } \\
\text { Isi (Content) }\end{array}$} & $\begin{array}{l}\text { Puas dengan kelengkapan } \\
\text { aplikasi SIP }\end{array}$ & 12 \\
\hline & & $\begin{array}{l}\text { SIP menghasilkan laporan yang } \\
\text { dibutuhkan }\end{array}$ & 13 \\
\hline & \multirow{3}{*}{$\begin{array}{l}\text { Tampilan } \\
\text { (Format) }\end{array}$} & $\begin{array}{l}\text { Puas terhadap tampilan aplikasi } \\
\text { SIP }\end{array}$ & 14 \\
\hline & & $\begin{array}{l}\text { SIP mampu memberikan } \\
\text { informasi sesuai format yang } \\
\text { dibutuhkan }\end{array}$ & 15 \\
\hline & & $\begin{array}{l}\text { SIP mampu menghasilkan } \\
\text { informasi yang dapat dipahami } \\
\text { secara jelas }\end{array}$ & 16 \\
\hline & $\begin{array}{l}\text { Kemudahan } \\
\text { (Ease of use) }\end{array}$ & $\begin{array}{l}\text { Aplikasi SIP tersebut mudah } \\
\text { untuk digunakan untuk pemula }\end{array}$ & 17 \\
\hline & Tepat Waktu & $\begin{array}{l}\text { Informasi yang dihasilkan SIP } \\
\text { tepat waktu }\end{array}$ & 18 \\
\hline
\end{tabular}

\subsection{Ruang Lingkup}

Ruang lingkup yang akan dibahas adalah adanya pengaruh antara kualitas sistem informasi terhadap kepuasan pengguna yang diambil dari studi kasus pada lembaga pendidikan SMA Al - Huda yang mengacu pada kuisioner yang telah dibagikan kepada 
guru yang menggunakan Sistem Informasi Penelitian (SIP) berdasarkan metode DELON dan MC Clean (1992) [3].

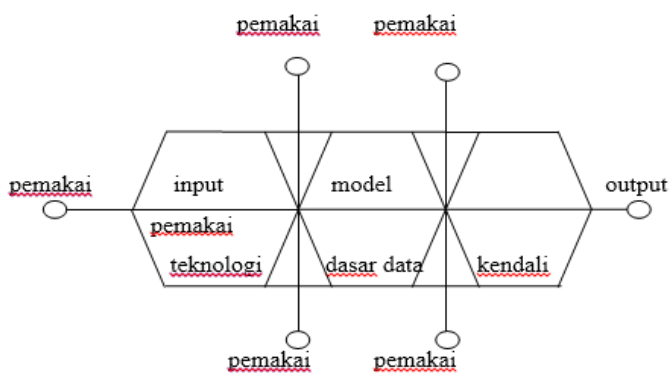

Gambar 3. Pengaruh Kualitas Sistem Informasi Terhadap Pengguna

\subsection{Sistem Informasi}

Sistem informasi adalah suatu sistem didalam suatu organisai yang mempertemukan kebutuhan pengolahan transaksi harian, mendukung operasi, bersifat manejerial dan kegiatan strategi dari suatu orgainisasi dan menyediakan pihak luartertentu dengan laporan-laporan yang diperlukan. [6]

\subsection{Hipotesis}

Hipotesa tersebut adalah :

Ho : Kualitas Sistem Informasi (quality system information) berpengaruh positif terhadap kepuasan pengguna.

$\mathrm{H}_{1}$ : Kualitas Sistem Informasi (quality system information) berpengarus positif terhadap ketidakpuasan terhadap pengguna.

\subsection{Tampilan Aplikasi}

\section{HASIL DAN PEMBAHASAN}

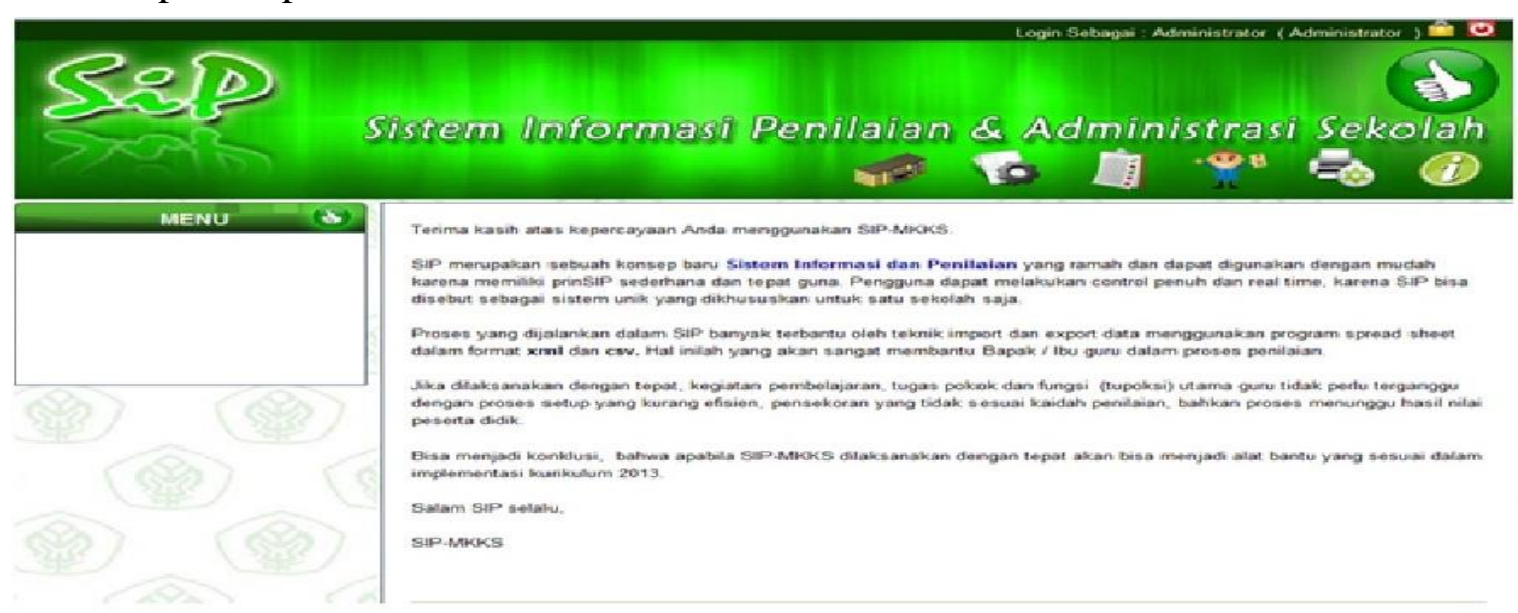

Gambar 4. Menu Home 


\section{Sistem informasi Penilaian of Administrasi Sekolah}

\section{Gambar 5. Menu Login}

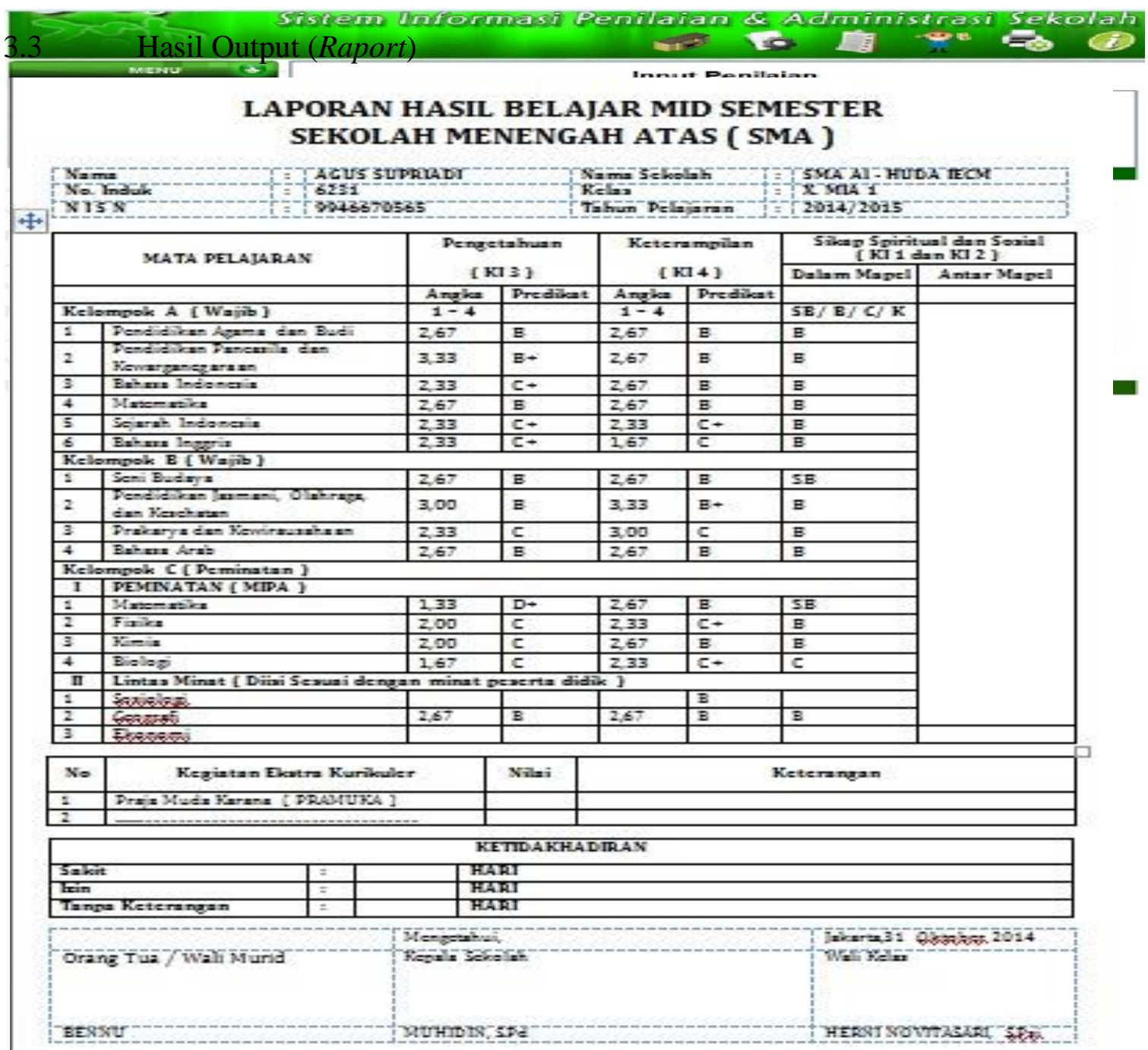

Gambar 6. Menu Input Nilai 


\section{2 \\ Uji Validitas dan Reliabilitas Kuisioner}

A. Responden

Responden dalam penelitian ini adalah karyawan/guru SMA A-Huda yang menggunakan sistem informasi penilaian (SIP). Adapun pengguna yang menggunakan adalah seluruh guru yang aktif menggunakan aplikasi SIP pada SMA Al-Huda. Populasi pengguna aktif SIP dalam penelitian ini adalah 42 orang dan dengan menggunakan rumus pedoman mementukan jumlah sampling. Maka diperoleh jumlah sampel yang diambil adalah 40.

Tabel 3: Output Deskripsi Responden Berdasarkan Jenis Kelamin

Jenis Kelamin

\begin{tabular}{|c|r|r|r|r|}
\hline & $\begin{array}{c}\text { Frequenc } \\
\mathrm{y}\end{array}$ & Percent & $\begin{array}{r}\text { Valid } \\
\text { Percent }\end{array}$ & $\begin{array}{l}\text { Cumulativ } \\
\text { e Percent }\end{array}$ \\
\hline Valid L & 16 & 40,0 & 40,0 & 40,0 \\
P & 24 & 60,0 & 60,0 & 100,0 \\
Tota & 40 & 100,0 & 100,0 & \\
1 & & & \\
\hline
\end{tabular}

Berdasarkan tabel diatas, diketahui bahwa frekuensi jumlah sampel Laki-laki (L) sebanyak 16 responden dengan presentase $40.0 \%$ dan frekuensi jumlah sampel Perempuan (P) sebanyak 24 responden dengan presentase $60.0 \%$. Dan dari perhitungan tersebut, data tabel diatas dinyatakan valid dan sesuai dengan jumlah keseluruhan sampel sebanyak 40 responden dengan presentase $100 \%$.

B. Uji Validitas

Validitas (validity) menunjukan bahwa suatu pengujian benar-benar mengukur apa yang harusnya diukur. [7]

Tabel 4: Tabel Validitas Keseluruhan Variabel

Item-Total Statistics

\begin{tabular}{|c|c|c|c|c|}
\hline & $\begin{array}{c}\text { Scale } \\
\text { Mean if } \\
\text { Item } \\
\text { Deleted }\end{array}$ & $\begin{array}{c}\text { Scale } \\
\text { Varianc } \\
\text { e if Item } \\
\text { Deleted }\end{array}$ & $\begin{array}{c}\text { Corrected } \\
\text { Item-Total } \\
\text { Correlation } \\
\end{array}$ & $\begin{array}{l}\text { Cronbach's } \\
\text { Alpha if } \\
\text { Item Deleted }\end{array}$ \\
\hline $\begin{array}{l}\text { Kualitas } \\
\text { Sistem }\end{array}$ & 48,6750 & 43,302 & ,834 & ,876 \\
\hline $\begin{array}{l}\text { Kualitas } \\
\text { Informasi }\end{array}$ & 52,2750 & 50,410 & ,838 & ,880 \\
\hline $\begin{array}{l}\text { Kepuasan } \\
\text { Pengguna }\end{array}$ & 44,1000 & 43,477 & ,831 & ,879 \\
\hline
\end{tabular}

C. Uji Reliabilitas

Reliabilitas (reliability) adalah suatu pengukur yang menunjukkan stabilitas dan konsistensi dari suatu instrumen yang mengukur suatu konsep. Definisi tersebut maka 
dapat disimpulkan bahwa reliabilitas menunjukan akurasi dan ketepatan dari pengukurnya.[7]

Tabel 5: Output SPSS Reliabilitas Variabel Kualitas Sistem, Kualitas Informasi dan Kepuasan Pengguna

\section{Scale: RELIABILITAS Scale: RELIABILITAS KUALITAS SISTEM} KUALITAS INFORMASI Scale: RELIABILITAS KEPUASAN PENGGUNA

\begin{tabular}{|c|c|}
\hline \multicolumn{2}{|c|}{$\begin{array}{c}\text { Reliability } \\
\text { Statistics }\end{array}$} \\
\hline $\begin{array}{l}\text { Cronbach's } \\
\text { Alpha }\end{array}$ & $\mathrm{N}$ of Items \\
\hline ,759 & 7 \\
\hline
\end{tabular}

\section{Reliability}

Reliability Statistics

\begin{tabular}{|r|r|}
\hline $\begin{array}{c}\text { Cronbach's } \\
\text { Alpha }\end{array}$ & N of Items \\
\hline, 760 & 5 \\
\hline
\end{tabular}

Statistics

\begin{tabular}{|r|r|}
\hline $\begin{array}{c}\text { Cronbach } \\
\text { s Alpha }\end{array}$ & $\begin{array}{c}\text { N of } \\
\text { Items }\end{array}$ \\
\hline, 760 & 5 \\
\hline
\end{tabular}

Dari hasil perhitungan tabel $5, \mathrm{R}_{\text {alpha }}$ untuk instrumen kualitas sistem adalah 0,762 , sedangkan nilai dari $\mathrm{R}_{\text {alpha }}$ kualitas informasi adalah 0,760 , nilai dan $\mathrm{R}_{\text {alpha }}$ kepuasan pengguna 0,759. Maka dapat disimpulkan bahwa diketahui nilai Cronbach Alpha tabel IV.3 rata-rata diatas 0,6. "reliabilitas kurang dari 0,6 adalah kurang baik, sedangkan 0,7 dapat diterima dan diatas 0,8 adalah baik. Karena menurutnya nilai lebih dari 0,6 instrumen kuisioner dinyatakan reliabel. Maka instrumen kuisioner variabel dalam penelitian ini dinyatakan reliabel. [8]

\subsection{Analisis Korelasi Pearson}

Dalam Korelasi Pearson, nilai koefisien korelasi berkisar antara 0 sampai 1 atau 0 sampai -1, nilai semakin mendekati 0 maka hubungan semakin lemah.

Tabel 6: Output SPSS Analisis Korelasi Pearson

\section{Correlations}

\begin{tabular}{|ll|r|r|r|}
\hline & \multicolumn{1}{|c|}{$\begin{array}{c}\text { Kualitas } \\
\text { Sistem }\end{array}$} & $\begin{array}{c}\text { Kualitas } \\
\text { Informasi }\end{array}$ & $\begin{array}{r}\text { Kepuasan } \\
\text { Pengguna }\end{array}$ \\
\hline $\begin{array}{ll}\text { Kualitas } \\
\text { Sistem }\end{array}$ & Pearson & 1 &, $794^{* *}$ &, $786^{* *}$ \\
& Sig. (2-tailed) & &, 000 &, 000 \\
& N & 40 & 40 & 40 \\
\hline Kualitas & Pearson &, $794^{* *}$ & 1 &, $789^{* *}$ \\
Informasi & Correlation &, 000 & & 40 \\
& Sig. (2-tailed) & 40 & 40 & \\
& $\mathrm{~N}$ & & \\
\hline
\end{tabular}




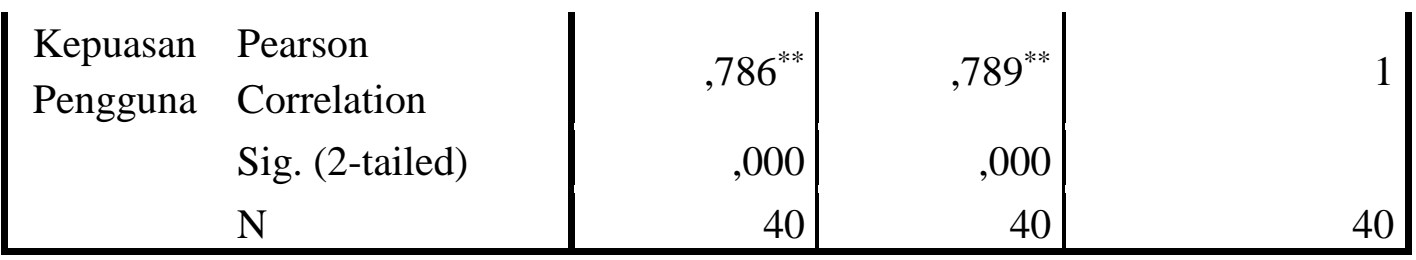

**. Correlation is significant at the 0.01 level (2-tailed).

Dari output diatas dapat dijelaskan bahwa :

Tabel 7: Output SPSS Koefisien (Uji t) sebesar 0,786.

\section{Coefficients $^{\mathrm{a}}$}

\begin{tabular}{|c|c|c|c|c|c|}
\hline \multirow[b]{2}{*}{ Model } & \multicolumn{2}{|c|}{$\begin{array}{l}\text { Unstandardize } \\
\text { d Coefficients }\end{array}$} & \multirow{2}{*}{$\begin{array}{c}\text { Standardized } \\
\text { Coefficients } \\
\text { Beta }\end{array}$} & \multirow[b]{2}{*}{$\mathrm{T}$} & \multirow[b]{2}{*}{ Sig. } \\
\hline & $\mathrm{B}$ & $\begin{array}{l}\text { Std. } \\
\text { Error }\end{array}$ & & & \\
\hline $1 \quad$ (Constant) & $\begin{array}{r}7,54 \\
2\end{array}$ & 2,319 & & $\begin{array}{r}3,25 \\
2\end{array}$ & ,002 \\
\hline Kualitas Sistem & ,431 &, 150 & ,431 & $\begin{array}{r}2,87 \\
1\end{array}$ & ,007 \\
\hline Kualitas Informasi & ,524 &, 176 & ,447 & $\begin{array}{r}2,97 \\
3\end{array}$ & ,005 \\
\hline
\end{tabular}

Dependent Variable: Kepuasan Pengguna

Karena koefisien mendekati 1, maka dapat disimpulkan bahwa antara Kualitas Sistem dengan Kepuasan Pengguna memiliki hubungan yang erat. Korelasi antara Kualitas Informasi dan Kepuasan Pengguna didapat nilai koefisien sebesar 0,789. Karena koefisien mendekati 1, maka dapat disimpulkan bahwa antara Kualitas Informasi dengan Kepuasan Pengguna memiliki hubungan yang erat.

\subsection{Analisis Regresi Linier Berganda (Multiple) \\ 1. Output Koefisien (Uji t)}

Keterangan tabel di atas adalah :

1. Unstandardized Coefficients adalah nilai koefisien yang tidak terstandarisasi atau tidak ada patokan, nilai ini menggunakan satuan yang digunakan pada data pada variabel dependen.

2. Standardized Coefficients adalah nilai koefisien yang telah terstandarisasi atau pada patokan tertentu, nilai koefisien Beta semakin mendekati nol maka hubungan antara variabel $\mathrm{X}$ dengan $\mathrm{Y}$ semakin lemah.

3. T Hitung ( $\mathrm{t}$ ) adalah pengujian signifikasi untuk mengetahui pengaruh variabel $\mathrm{X} 1$ dan X2 terhadap Y secara parsial, apakah berpengaruh signifikan atau tidak. Untuk mengetahui hasil signifikan atau tidak angka thitung dibandingkan dengan t tabel.

4. Signifikasi (Sig) adalah besarnya probabilitas atau peluang untuk memperoleh kesalahan dalam mengambil keputusan jika pengujian menggunakan tingkat signifikasi 0,05 artinya peluang memperoleh kesalahan maksimal 5\%. Dengan Kata lain kita percaya bahwa 95\% keputusan adalah benar. [8] 
Tabel 8:

Output SPSS Anova (Uji F)

\begin{tabular}{|c|c|c|c|c|c|}
\hline \multicolumn{6}{|c|}{ ANOVA $^{a}$} \\
\hline Model & $\begin{array}{l}\text { Sum of } \\
\text { Squares }\end{array}$ & $\mathrm{df}$ & $\begin{array}{c}\text { Mean } \\
\text { Square }\end{array}$ & $\mathrm{F}$ & Sig. \\
\hline 1 Regression & 380,036 & 2 & 190,018 & $\begin{array}{r}41,42 \\
1\end{array}$ & $\begin{array}{r}, 00 \\
0^{\mathrm{b}}\end{array}$ \\
\hline Residual & 169,739 & 37 & 4,588 & & \\
\hline Total & 549,775 & 39 & & & \\
\hline
\end{tabular}

a. Dependent Variable: Kepuasan Pengguna

b. Predictors: (Constant), Kualitas Informasi, Kualitas

Sistem

Dari tabel 8 diperoleh $\mathrm{F}$ hitung sebesar 41,421 dan nilai signifikansi sebesar 0,000, dan diperoleh $\mathrm{F}$ tabel sebesar 3,252. Maka dapat disimpulkan bahwa $\mathrm{F}$ hitung $>\mathrm{F}$ tabel $(41,421>3,252)$ dan probabilitas $(0,000)$ jauh lebih kecil dari 0,05 , sehingga bisa dikatakan bahwa Kualitas Sistem dan Kualitas Informasi secara bersama-sama berpengaruh terhadap kepuasan Pengguna.

Arti angka-angka tersebut adalah :

A. Nilai konstanta (a) sebesar 7,542, ini dapat diartikan jika Kualitas Sistem dan Kualitas Informasi nilainya adalah 0, maka nilai kepuasan pengguna Sistem Informasi Penilaian sebesar 7,542.

B. Nilai koefisien Kualitas Sistem bernilai positif, yaitu sebesar 0,431; maka ini dapat diartikan bahwa setiap peningkatan Kualitas Sistem sebesar 1 satuan, maka akan meningkatkan kepuasan pengguna sebesar 0,431 satuan dengan asumsi variabel independen lain nilainya tetap.

C. Nilai koefisien Kualitas Informasi bernilai positif, yaitu sebesar 0,524; maka ini satuan dapat diartikan bahwa setiap peningkatan Kualitas Informasi sebesar 1 satuan, maka akan meningkatkan kepuasan pengguna sebesar 0,524 satuan dengan asumsi variabel independen lain nilainya tetap.

Dari penjelasan-penjelasan tersebut diperoleh :

1. T hitung Kualitas Sistem $>$ t tabel $(2,871>1,686)$

2. T hitung Kualitas Informasi $>t$ tabel $(2,973>1,686)$

3. Signifikansi Kualitas Sistem dan Kualitas Informasi sebesar 0,000,

Maka dapat disimpulkan bahwa t hitung kedua variabel lebih besar dari t tabel dengan signifikansi 0,000 jauh lebih kecil dari 0,05, sehingga bisa dikatakan bahwa Kualitas Sistem dan Kualitas Informasi secara bersama-sama berpengaruh terhadap Kepuasan Pengguna.

3. Pengujian Hipotesis

Kriteria pengujian hipotesis adalah :

1. Jika Statistik Hitung (angka $\mathrm{t}$ output) $>$ Statistik Tabel (tabel t) maka $\mathrm{H}_{0}$ ditolak 
2. Jika Statistik Hitung (angka $\mathrm{t}$ output) $<$ Statistik Tabel (tabel t) maka $\mathrm{H}_{0}$ diterima

Dan bila berdasarkan probabilitas adalah :

1. Jika probabilitas $>0,05$ maka $\mathrm{H}_{0}$ diterima

2. Jika probabilitas $<0,05$ maka $\mathrm{H}_{0}$ ditolak

Untuk pengujian hipotesis adalah sebagai berikut :

Ho : Kualitas sistem informasi (quality system information) berpengaruh positif terhadap kepuasan pengguna.

$\mathrm{H}_{1}$ : Kualitas sistem informasi (quality system information) tidak berpengaruh positif terhadap kepuasan pengguna.

Dari hasil perhitungan tabel 7 signifikansi untuk variabel kualitas sistem adalah 0,000 . Sehingga nilai probabilitas $0,000<0,05$ dan nilai $t$ hitung 2,871 lebih besar dari t tabel yaitu 1,686, dapat diambil keputusan bahwa Ho diterima. Juga dapat dilihat bahwa signifikansi untuk variabel kualitas informasi adalah 0,000 Sehingga nilai probabilitas $0,000<0,05$ dan nilai $t$ hitung 2,973 lebih besar dari t tabel yaitu 1,686, dapat diambil keputusan bahwa $\mathrm{H}_{1}$ diterima.

Hipotesis dalam penelitian tabel tersebut juga menyatakan bahwa kualitas sistem informasi dan kualitas informasi memiliki pengaruh terhadap kepuasan pengguna Sistem Informasi Penilaian (SIP) dengan kesimpulan sebagai berikut :

Nilai signifikansi t untuk kualitas sistem lebih kecil dari $\alpha$ yang ditetapkan $(\alpha=0,05)$ yaitu 0,000. Selain itu, hasil pengujian ini juga menunjukkan nilai $t$ hitung lebih besar dari nilai $t$ tabel $(2,871>1,686)$ untuk kualitas sistem informasi, dan t hitung lebih besar dari t tabel $(2,973>1,686)$ untuk kualitas informasi. Berdasarkan hasil pengujian tersebut maka dapat disimpulkan bahwa $\mathrm{H}_{1}$ akan ditolak dan Ho diterima, artinya bahwa kualitas sistem informasi memiliki pengaruh yang signifikan terhadap kepuasan pengguna sistem informasi.

\section{KESIMPULAN}

Hasil Uji Validitas X1 (0,595), X2 $(0,626)$ dan Y (0.562), mendapatkan bukti bahwa seluruh variabel penelitian memiliki nilai diatas $R_{\text {tabel }}(0,2638)$ sehingga seluruh variabel pernyataan dinyatakan valid.

Berdasarkan hasil uji regresi secara linier berganda (multiple) didapatkan hasil $\mathrm{R}$ $(0,831)$ mendekati 1 maka korelasi antara variabel Kualitas Sistem dan Kualitas Informasi memiliki hubungan yang erat. Dan hasil $\mathrm{R}$ Square $\left(\mathrm{R}^{2}\right)$ atau kuadrat dari $\mathrm{R}$ yang menghasilkan nilai sebesar 0,691 sumbangan pengaruh variabel Kualitas Sistem dan Kualitas Informasi terhadap Kepuasan Pengguna.

Dalam perhitungan uji $\mathrm{F}$ diperoleh $\mathrm{F}$ hitung sebesar 41,421 dan nilai signifikansi sebesar 0,000, dan diperoleh $\mathrm{F}$ tabel sebesar 3,252. Maka dapat disimpulkan bahwa $\mathrm{F}$ hitung > F tabel $(41,421>3,252)$ dan probabilitas $(0,000)$ jauh lebih kecil dari 0,05 , sehingga bisa dikatakan bahwa Kualitas Sistem dan Kualitas Informasi secara bersamasama berpengaruh terhadap kepuasan Pengguna.

Berdasarkan uji T diperoleh $\mathrm{T}$ hitung Kualitas Sistem $>\mathrm{t}$ tabel $(2,871>1,686), \mathrm{T}$ hitung Kualitas Informasi > t tabel $(2,973>1,686)$ dan Signifikansi Kualitas Sistem sebesar 0,007 dan Kualitas Informasi sebesar 0,005. Maka dapat disimpulkan bahwa t hitung kedua variabel lebih besar dari t tabel dengan signifikansi 0,007 dan 0,005 jauh lebih kecil dari 0,05, sehingga bisa dikatakan bahwa Kualitas Sistem dan Kualitas Informasi masing-masing secara parsial berpengaruh terhadap Kepuasan Pengguna. 


\section{SARAN}

Untuk mengetahui keakuratan dari penelitian ini, disarankan untuk menguji dengan metode lain. Sehingga dapat di buat komparasi mengenai hasil penelitian.

\section{UCAPAN TERIMA KASIH}

Terima kasih kepada Manajemen SMA Al-Huda, siswa siswi, serta guru guru di lingkungan sekolah. yang sudah membantu penulis dalam penelitian ini. Keluarga dan pihak penerbit jurnal, atas kesempatannya dalam mempublikasi karya ilmiah ini.

\section{DAFTAR PUSTAKA}

[1] Baridwan, Hanum. 2007. Kualitas Dan Efektivitas Sistem Informasi Berbasis Komputer, Brawijaya: Vol.8 No.2 September 2007.

[2] Purwaningsih, Susanti. 2010. Analisis Kesuksesan Penerapan Sistem Informasi Pada Sistem Informasi Pelayanan Terpadu (SIPT) Online: Studi Pada PT. Jamsostek (PERSERO). ISSN 1693-928X. Semarang: Jurnal Aset, Februari 2010 Vol. 12 No. 2. Diambil dari: http://jurnal.widyamanggala.ac.id/index.php/asetwm/article/view/39.

[3] DeLone, W.H. and E.R.Mc Lean. 1992." Information System Success: The Quest for the Dependent Variable" Infomation System Research 3 (Marach)

[4] Prasetyo, Bambang dan Lina Miftahul Jannah. 2011. Metode Penelitian Kuantitatif. Jakarta: Kharisma Putra Utama Offset.

[5] Sugiyono. 2010. Metode Penelitian Kuantitatif Kualitatif dan R\&D. Bandung: Alfabeta.

[6] Jogiyanto. 2005. Analisis dan Desain Sistem Informasi: Pendekatan Terstruktur Teori dan Praktik Aplikasi Bisnis. Yogyakarta: Andi Offset.

[7] Jogiyanto. 2008. Metodologi Penelitian Sistem Informasi. Yogyakarta: Andi Offset.

[8] Priyatno, Duwi. 2014. SPSS 22: Pengolahan Data Terpraktis. Yogyakarta: Andi Offset. 